Georgia State University

ScholarWorks @ Georgia State University

Spring 4-2018

\title{
Higher Education Pricing: Effects of Tuition Pricing on Nontraditional Student Persistence Moderated by Demographics.
}

Katherine Crowell Spradley

Follow this and additional works at: https://scholarworks.gsu.edu/bus_admin_diss

\section{Recommended Citation}

Spradley, Katherine Crowell, "Higher Education Pricing: Effects of Tuition Pricing on Nontraditional Student Persistence Moderated by Demographics.." Dissertation, Georgia State University, 2018.

doi: https://doi.org/10.57709/12467820

This Dissertation is brought to you for free and open access by the Programs in Business Administration at ScholarWorks @ Georgia State University. It has been accepted for inclusion in Business Administration Dissertations by an authorized administrator of ScholarWorks @ Georgia State University. For more information, please contact scholarworks@gsu.edu. 


\section{PERMISSION TO BORROW}

In presenting this dissertation as a partial fulfillment of the requirements for an advanced degree from Georgia State University, I agree that the Library of the University shall make it available for inspection and circulation in accordance with its regulations governing materials of this type. I agree that permission to quote from, copy from, or publish this dissertation may be granted by the author or, in her absence, the professor under whose direction it was written or, in his absence, by the Dean of the Robinson College of Business. Such quoting, copying, or publishing must be solely for scholarly purposes and must not involve potential financial gain. It is understood that any copying from or publication of this dissertation that involves potential gain will not be allowed without written permission of the author.

Katherine Crowell Spradley 


\section{NOTICE TO BORROWERS}

All dissertations deposited in the Georgia State University Library must be used only in accordance with the stipulations prescribed by the author in the preceding statement.

The author of this dissertation is:

Katherine Crowell Spradley

J. Mack Robinson College of Business

Georgia State University

Atlanta, Georgia 30303

The director of this dissertation is:

Wesley Johnston

J. Mack Robinson College of Business

Georgia State University

Atlanta, GA 30302-4015 
Higher Education Pricing: Effects of Tuition Pricing on Nontraditional Student Persistence Moderated by Demographics.

by

Katherine Crowell Spradley

A Dissertation Submitted in Partial Fulfillment of the Requirements for the Degree

Of

Executive Doctorate in Business

In the Robinson College of Business

Of

Georgia State University

GEORGIA STATE UNIVERSITY

ROBINSON COLLEGE OF BUSINESS

2018 
Copyright by

Katherine Crowell Spradley 2018 


\section{ACCEPTANCE}

This dissertation was prepared under the direction of the KATHERINE CROWELL SPRADLEY Dissertation Committee. It has been approved and accepted by all members of that committee, and it has been accepted in partial fulfillment of the requirements for the degree of Doctor of Philosophy in Business Administration in the J. Mack Robinson College of Business of Georgia State University.

Richard Phillips, Dean

\section{DISSERTATION COMMITTEE}

Dr. Wesley J. Johnston (Chair)

Dr. Patricia G. Ketsche

Dr. Danny Bellinger 


\section{ACKNOWLEDGEMENTS}

The support of many individuals has been key during the preparation of this dissertation. A very special thank you to the University that assisted in providing the data making this dissertation possible and meaningful. Although the University wishes to remain anonymous, their contributions to this process have been invaluable. It is my hope that they reap the expected benefits and more as a result of their gracious participation and support in this study. Thank you to Georgia State University for allowing me the opportunity to be challenged as a part of their doctorate program and providing a robust learning experience.

A tremendous thank you to my dissertation committee for their guidance, assistance, and confidence during this process. Thank you to Dr. Wesley Johnston, my chair and advisor, for his patience and counsel that was crucial to the success of this study. Thank you to Dr. Patricia Ketsche for the extra assistance with the technical aspects of modeling and analysis, and Dr. Danny Bellinger for the valuable suggestions and encouragement that helped move this study to completion. Thank you to Shalini Gopalkrishnam and Lowell Thomas Ferguson for their assistance with the data analysis and review.

Thank you to my professors in the doctorate program and my colleagues for challenging me to reach new depths of understanding and abilities, providing both the tools and encouragement to complete this program and dissertation. Thank you to my classmates and fellow alumni who have made the journey through this program invaluable from the networking opportunities, friendships, and guidance shared. Thank you to my friends, near and far, that supported me, inspired me, lifted me up, and pushed me during this journey. Your steadfast prayers and unwavering faith in my abilities mean the world to me.

Thank you to Seth Spradley, as the sacrifices that you made for our family to support the long periods of reading, studying, researching, writing, and traveling are forever acknowledged. 
Your emotional support gave me the strength to handle the delicate balance of working two jobs, taking care of our family, and finishing this milestone. Thank you to my children, Henry, Charles, and Nev, as you were my inspiration to push harder, fueling my heart with strength needed to make you proud. Thank you to my parents, Frank and Deanne Crowell, for the love, time spent with our children, and support throughout my educational journey. To my family as a whole, thank you for believing in me and supporting my aspirations without once allowing doubt to be a part of my vocabulary. Your prayers for my success were coveted and appreciated. 


\section{TABLE OF CONTENTS}

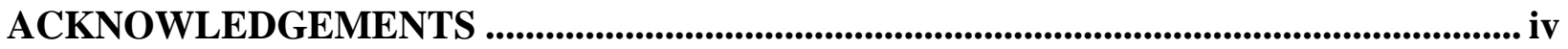

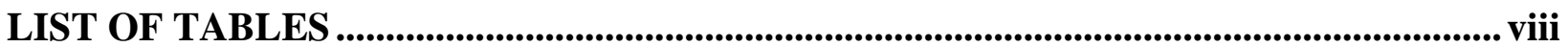

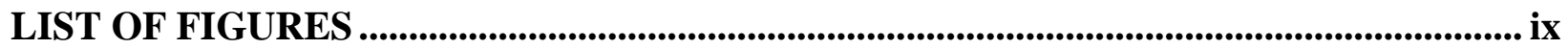

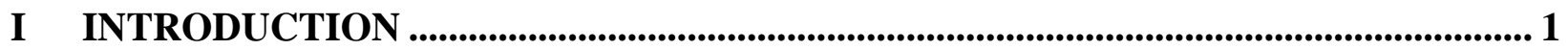

I.1 Research Domain .................................................................................................................. 1

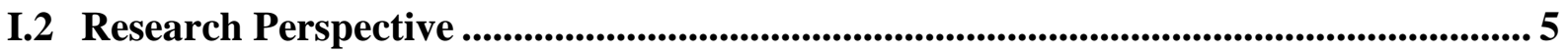

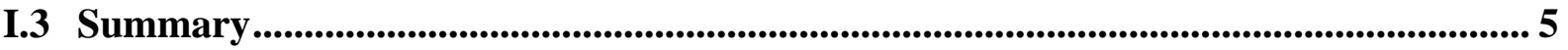

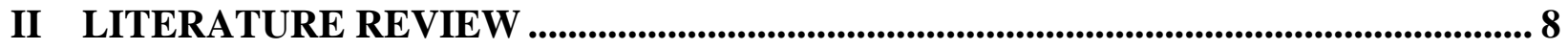

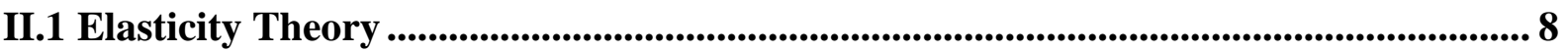

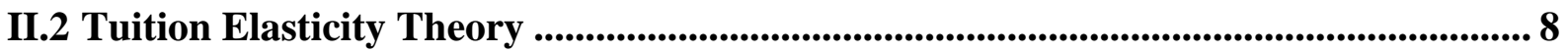

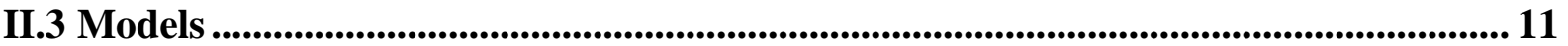

II.3.1 The Tuition Elasticity and Net Earning Projections (TENEP) model ............. 15

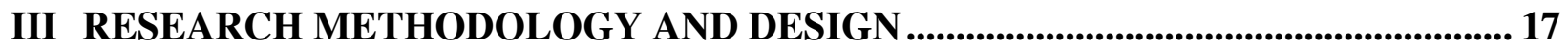

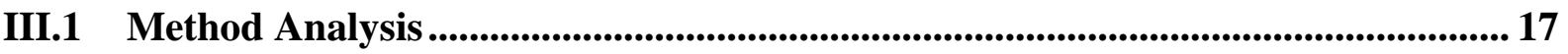

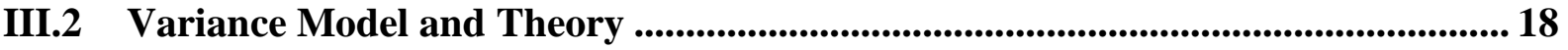

IV DATA COLLECTION AND ANALYSIS AND RESULTS ...................................... 20

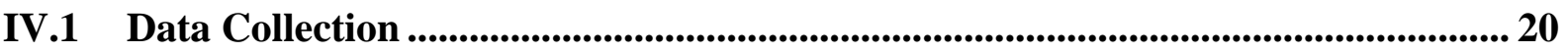

IV.2 Data Description ....................................................................................................... 20

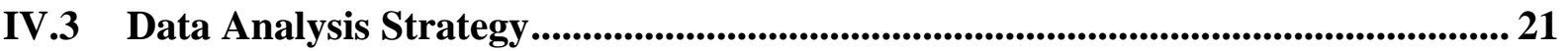

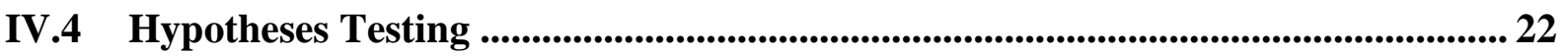

IV.4.1 Tuition Effects on Persistence for Nontraditional Students ......................... 23

IV.4.2 Tuition Effects on Persistence for Nontraditional Online Students .............. 24

IV.4.3 Tuition Effects on Persistence for Nontraditional Military Students ........... 24 
IV.4.4 Tuition Effects on Persistence for Nontraditional Female Students............ 25

IV.4.5 Tuition Effects on Persistence for Nontraditional Minority Students........... 26

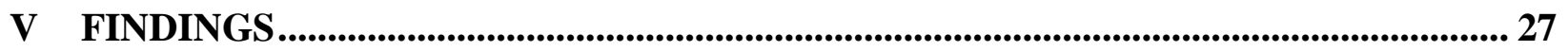

V.1 Hypotheses and Results ...................................................................................................... 27

V.2 Linear Regression Model Selection and Justification ............................................... 28

V.3 Effect of Tuition Increase on Nontraditional Persistence ........................................ 30

V.4 Effect of Tuition Increase on Nontraditional Persistence by Demographic............... 31

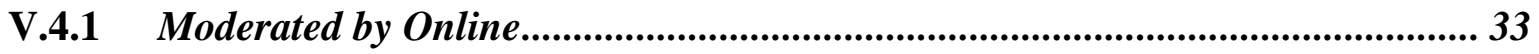

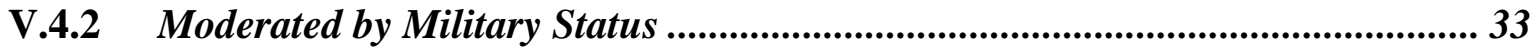

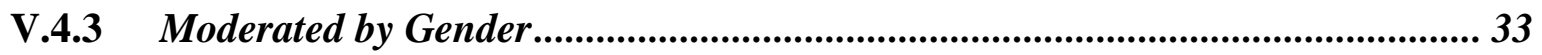

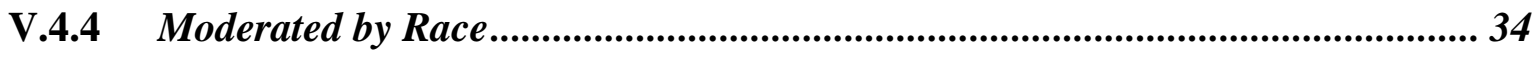

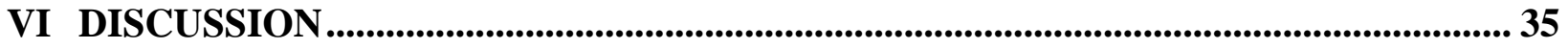

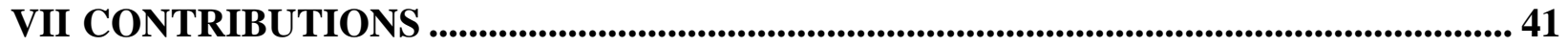

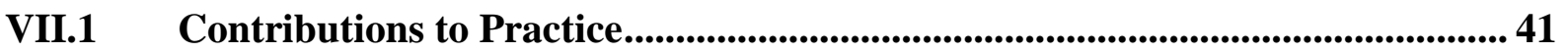

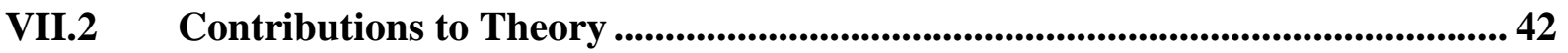

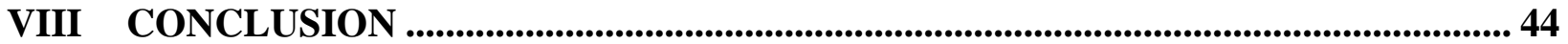

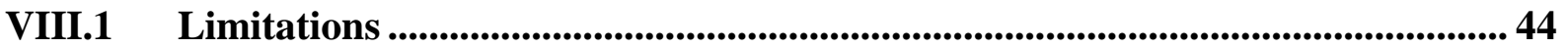

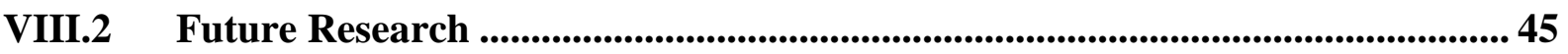

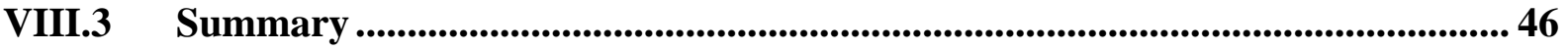

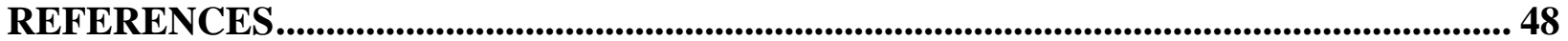

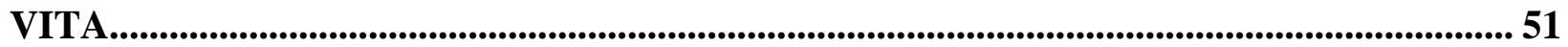




\section{LIST OF TABLES}

Table 1 Summary of Traditional Student Elasticities ..................................................................... 10

Table 2 Models in Tuition Pricing ............................................................................................ 14

Table 3 Selected Military Pay Grades and Base Ranges per Month ...................................... 25

Table 4 Summary of Hypotheses and Results .................................................................. 28

Table 5 Summary of Mean Variables ............................................................................... 29

Table 6 Summary of Persistence ......................................................................................... 31

Table 7 Summary of Nontraditional Persistence by Demographic......................................... 32

Table 8 Average Tuition Price Increase by Percent ...................................................................... 36 


\section{LIST OF FIGURES}

Figure 1 Shifting Focus from Traditional Students to Nontraditional Students ................... 13

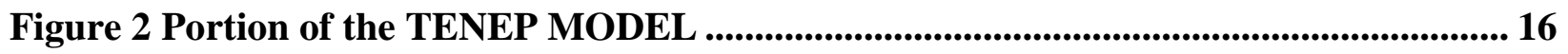

Figure 3 Conceptual Model for Constructs and Hypotheses .................................................. 23 


\begin{abstract}
Higher Education Pricing: Effects of Tuition Pricing on Nontraditional Student Persistence Moderated by Demographics.
\end{abstract}

by

Katherine Crowell Spradley

August 2018

Chair: Wesley Johnston

Major Academic Unit: Executive Doctorate in Business

Higher education pricing models have focused heavily on traditional student population analysis, net earnings, financial aid, and enrollment projections or unduplicated headcount. As the population of students shifts to a nontraditional majority, research of the effect of tuition price on nontraditional population segments is needed with a focus on persistence (the likelihood of re-enrollment in the next semester for a given student) rather than overall enrollment levels. It becomes prudent to re-evaluate pricing models and the associated coefficients from tuition pricing changes on persistence to more effectively serve the nontraditional population as nontraditional students rely less on financial aid and progress through their curriculum at individualized pace consistent with their needs. The nontraditional population is, on average, older, with more professional experience, often with military affiliations (active duty, veteran, reservist, or family member), and education in progress. Using a quantitative longitudinal empirical case study, the researcher utilized student level data from a private, nonprofit university in the Commission on Colleges of the Southern Association of Colleges and Schools regional accreditation territory to determine the effect of a tuition increase on nontraditional 
student (age 25+) persistence. The data was analyzed using a linear regression interaction model in STATA.

The researcher found statistical significance, with the counterintuitive finding that the effect of a 1 percent tuition increase for all students was an increase in persistence by 2.01 percent with a clear explanation for this finding of the overall tuition effect on persistence. Consistent with theory, this research finds that nontraditional students only increased their persistence by 0.62 percent, persisting less than traditional students. For every 1 percent increase in tuition, nontraditional online students are decreasing their persistence by 0.9 percent, persisting less than face-to-face students. These findings are important, as they provide contributions to Elasticity Theory, Tuition Elasticity Theory, and practice including application for higher education institutions, administrators and advisors in higher education, and customer relationship management software as service companies targeting students utilizing variations of predictive analytics to estimate persistence of different populations, estimate and understand tuition price increase effects on different populations, set recruiting and enrollment goals based upon expected attrition, and design customized communication plans to facilitate more in-depth relationships with those less likely to persist in an effort to overcome this statistic. These findings are also the first portion of exploring elasticities as they apply toward developing a pricing model for nontraditional student populations using the framework established by the TENEP model (Bryan \& Whipple, 1995).

INDEX WORDS: higher education, tuition pricing, tuition elasticity theory, elasticity theory, pricing models, nontraditional students, persistence, enrollment, online, face-to-face 


\section{INTRODUCTION}

\section{I.1 Research Domain}

Since 1967, the pricing of higher education institutions has been studied (Campbell \& Siegal, 1967). From a sociological and economic perspective, "low-income and minority students' under-investment in higher education may lead to a widening gap in college participation and a reduction in socioeconomic mobility, a solid understanding of the role of price responsiveness in student demand for college is critical to help maintain the enrollments of underrepresented students." (Kim, 2010). From a finance and accounting perspective, pricing allows institutions to maximize profits by delicately balancing expenses and revenues without negatively impacting enrollment and retention.

Higher education pricing models focus on the traditional student population attending brick and mortar institutions utilizing face-to-face instruction with a focus on taxpayer dollars funding a portion of the tuition bill (Fethke \& Policano, 2013). Until recently, the traditional student population (referring to institutions serving 18-24 year olds) has been the majority of the population of students attending college/university classes; however, over the last six years this majority has shifted to nontraditional students (with the distinguishing factor being age 25+) (Jenkins, 2012) as the majority of students attending college/university classes both face-to-face and online. During this same timeframe, shift in the amount of taxpayer funding [both Federal and State] to student funding of tuition also occurred (Fethke, 2014). In fact, state support shows an overall decline since 2005 from $61.7 \%$ to $51.1 \%$ in 2014 , while national funding shows an overall decline since 2001 of $26.9 \%$ (SHEEO, 2014).

The expense of administering programs to nontraditional student populations varies from the expense of administering the programs to traditional student populations beginning with the 
cost of human resources (faculty and staff), real estate (building lease), and student life offerings (intramural sports, student center activities, etc.). In the nontraditional student population other expenses may be realized including the expense of delivering classes and programs online. “Some schools' administrators discovered that online programs were more costly than they had expected, and so they retrenched" (Smith \& Mitry, 2008). Thus, while some may assume that nontraditional programs are less expensive to administer, many times this could not be further from reality. The expense variable is a large part of the pricing model employed by many higher education institutions. With expenses differing between traditional student populations and nontraditional student populations, this further strengthens the argument for differentiated pricing models for each student population.

Retention has historically been measured by higher education institutions as the students' ability to enroll year after year as a first-time, full-time student to graduation within a set timeframe by IPEDS definitions (NCES, 2017); however, in the online and nontraditional sectors this measurement is often referred to as persistence. There has been little to no research on effect of the tuition price model on persistence for nontraditional students; however, there has been quite a bit of research on enrollment (unduplicated headcount) and thus it is assumed that since students are price responsive to enrollment decisions, that they also must be price responsive to persistence decisions. This study assumes that an increase in tuition dollars will have an effect on nontraditional student populations' likelihood of persisting utilizing the rationale that tuition dollars have an effect on traditional student populations' likelihood of enrollment. Further, research shows differences in the tuition effect on the likelihood of traditional student populations enrollment by demographics suggesting that the same research should be conducted for the nontraditional student population. 
Higher education tuition pricing model research, through tuition elasticity effects on nontraditional students by demographic, determining the importance of the tuition pricing between nontraditional and traditional student populations, is needed to help identify if price differentiation is warranted for nontraditional students from traditional students in maintaining persistence. In 2011 Hemelt and Marcotte noted that elasticities had not changed since studies conducted in the 1980s and 1990s (Hemelt \& Marcotte, 2011). This is not surprising given that the majority of the student population studied is from the traditional student population of 18 to 24 year old. This concept will be explored as this study seeks to determine the effect of a tuition increase on persistence as a component of tuition pricing and elasticity as the first stepping stone to determining if differentiated tuition pricing models for nontraditional student populations is warranted.

Several private, nonprofit institutions in the Commission on Colleges of the Southern Association of Colleges and Schools regional accreditation area offer varied pricing models to nontraditional students from that of their traditional student population profile. The question is raised, what effect does the tuition pricing have on nontraditional student persistence by segmented population? At one particular private, nonprofit University, a struggle exists in knowing whether to differentiate pricing for nontraditional students from traditional students, across multiple campuses and instructional methods. In order to effectively evaluate this dilemma, the effect of tuition price must be studied in the nontraditional student population as a first step to solving the dilemma. In order to effectively evaluate the effects of tuition price increases, the focus was on net tuition (St. John, 1994) as the University itself did not provide any institutional financial aid to the students attending the campuses studied. The studied University has multiple campus locations as well as an online program for their nontraditional 
population and became the subject of this case study due to the availability of data and interest of administration applying theory to practice. Although the courses offered at this University are identical for the traditional and nontraditional populations, the programs and instructional methods vary by location and the overhead expenses of administering those programs varies by instructional method (online or face-to-face instruction), setting the stage for price differentiation by nontraditional student population segment.

Variables that will be considered in this research include: demographics (the age of the student, gender of the population, race of the population, instructional method of the student, veteran status of the student, active duty status of the student) and student type (undergraduate). Additional considerations must be given to per credit hour charges, tuition discounting, merit scholarships, rate locking, military benefits, and lower/upper tier pricing variables by program (Fethke, 2014). These factors will not be utilized in this research as several including tuition discounting are no applicable and data for others such as governmental financial aid was not available at the time of this study. Additional questions that may be answered by reviewing these variables include if the effect of an increase in tuition affect certain demographic persistence rates differently.

Because of the variables that must be considered, some assumptions about the research must be made:

1. There are four types of four-year institutions (private for-profit, public for-profit, private nonprofit, and public nonprofit). This research will only be focused on private, nonprofit institutions, although the research may be applied to other institutions including for-profit and public institutions. 
2. Location is assumed to be in-state institutions so as to not introduce the variable of in-state versus out-of-state tuition. Location will not be considered, although the University selected for review is a member of the Commission on Colleges of the Southern Association of Colleges and Schools accreditation region.

\section{I.2 Research Perspective}

Through the lens of an empirical longitudinal case study utilizing the foundational constructs from Price Elasticity Theory of Demand and Tuition Elasticity Theory, the researcher will seek to answer the question of what is the effect of a tuition increase on nontraditional student population persistence and, additionally, the effect by segmented nontraditional student population. This type of research helps investigate the evidence-based knowledge that either confirms the success of moving toward differentiated tuition pricing models as it relates to nontraditional student persistence or provides reasons for the exploration of alternative solutions through learned knowledge that helps create new models if needed through direct and indirect observation and experience. To begin constructing and analyzing the models, the effect of an increase in tuition on nontraditional student persistence must first be understood.

\section{I.3 Summary}

This research study is organized as follows:

\section{Chapter 2: Literature Review}

This chapter reviews the previous research in the tuition pricing as it relates to Elasticity Theory and Tuition Elasticity Theory. In addition, it provides a brief overview of the terminology involved in this study including higher education aid and expenses, retention, persistence, and traditional versus nontraditional students. This chapter also explores several models that have been used in the past as pricing models for higher education institutions and 
describes the reasons for needing to study the effect of an increase in tuition on nontraditional persistence as a component of pricing models.

\section{Chapter 3: Research Methodology and Design}

Chapter 3 describes the research methodology and approach that this study utilizes to answer the "what" question in regard to the effects of tuition increases on nontraditional persistence using a quantitative approach. What effects does a tuition dollar increase have on persistence of nontraditional students and, further, what are the effects specific to certain demographics for nontraditional student populations. This longitudinal panel data linear regression study examines these effects on persistence at a student level.

\section{Chapter 4: Data Collection and Analysis and Results}

Chapter 4 elaborates on the data collection, analysis, and results of the study data spanning a period of five academic years for a total of four persistence observations per student using a student level data set from a private, nonprofit institution of higher learning.

\section{Chapter 5: Findings}

This chapter reviews the findings of the effects of a tuition increase on nontraditional students then focusing on the moderating effect of online and face-to-face delivery, military affiliations, gender, and race of nontraditional student populations developing a linear regression model applicable to nontraditional student populations showing statistical significance with nontraditional and online populations.

\section{Chapter 6: Discussion}

This chapter discusses the findings in view of the literature review of traditional student populations of what was known and what is known now about the nontraditional student population. This chapter further argues the new contributions of the findings of this study toward 
the problem of solving the dilemma of differentiated pricing models for nontraditional student populations.

\section{Chapter 7: Contributions}

This chapter reviews the four major contributions to theory and practice including the utilization of the findings by higher education institutions and administrators, researchers, and customer relationship management software companies targeting educational institutions.

\section{Chapter 8: Conclusion}

This chapter highlights the limitations of this study as it relates to the institution studied and the validity, reliability, and availability of student data from the source. The chapter emphasizes the generalizability of the data as well as the opportunities for future research

including additional demographic populations, elasticities, expenses, and pricing model application in reference to military, female, and minority nontraditional student populations. 


\section{LITERATURE REVIEW}

\section{II.1 Elasticity Theory}

Price Elasticity Theory of Demand is to first "show (1) how elasticity changes along the function and (2) how these elasticities are related to total expenditure at alternate prices and quantities" (Houck, 1967). This theory is used to classify a market as elastic, meaning demand is highly responsive to small pricing changes or as inelastic, meaning demand is not responsive or not very responsive to pricing changes. As this field was applied to higher education, the Theory of Tuition Elasticity was developed.

\section{II.2 Tuition Elasticity Theory}

Tuition prices have long been the discussion of many administrators in academia second to return on investment of education (Leslie \& Brinkman,1987). The need to balance increasing expenses with adequate revenue is a constant struggle for many in academia seeking to optimize enrollment while maximizing profit for both traditional (on campus) students as well as nontraditional online students. A focus on tuition elasticity of nontraditional students can help design this model beginning by exploring the effect of a tuition increase on nontraditional student persistence.

One issue affecting elasticity is the availability of the good or service. The more substitutes or alternatives to which a student has access, results in a higher elasticity for the good or service. In 2010, Kim notes that, "When competing institutions are considered as substitutes for other institutions, the cross-price elasticity of demand for enrollment relates the percentage change in enrollment to the percentage change in the tuition charged by the competing institutions. A positive value of cross-price elasticity indicates that the education offered by one 
institution is considered to be a substitute for the services provided by a competing institution." (Kim, 2010).

The literature surrounding tuition elasticity focuses on the 18-24 year old population completing a four-year degree bringing to light two issues (Leslie \& Brinkman,1987). The first issue is the majority of students attending post-secondary education has shifted from the traditional population (age 18-24) to the nontraditional student population becoming the majority (Jenkins, 2012). Secondly, quite a few studies reviewed by Leslie and Brinkman concentrated on freshman enrollment. While this focus is great for studying enrollment, it neglects to consider that traditional upperclassmen students are less likely to be impacted by tuition increases. It was also noted that tuition declines had significantly greater impact than tuition increases (Leslie \& Brinkman,1987).

In the studied traditional student population, four-year tuition elasticity is said to be relatively inelastic as compared to two-year tuition elasticity due to two-year institutions targeting and appealing more to lower income and older student populations (Leslie \& Brinkman,1987). This finding that lower income populations tended to be more elastic than higher income populations was further supported by Kane in 1995. In fact, the difference pointed out by Heller noted that the increase in tuition of two-year institutions, "resulted in a drop of total public enrollment of 3.5 percentage points. Similarly, an increase at the four-year colleges resulted in a total enrollment decrease of only 1.4 percentage points" (Heller, 1997, p628). This research may indicate that nontraditional student populations and lower income students will be more sensitive to tuition dollar increases. Furthermore, in 1972, Funk noted that tuition elasticity tended to be more inelastic for private institutions versus public institutions due to the fact that these institutions tended to attract higher income students (Funk, 1972). This research confirms 
the observations from Leslie and Brinkman that lower income students appear to be more sensitive to tuition dollar increases. In 2015, Byrd, Roufagalas, and Mixon estimated the elasticity of tuition for public four-year online students to be highly elastic in comparison to public four-year face-to-face traditional students, who were inelastic. On an interesting note, the review of more than twenty-five studies on tuition elasticity resulted in the suggestion that perhaps each institution needs its own elasticity model (Leslie \& Brinkman,1987) further supporting differentiated pricing in the higher education market. See Table 2.2 for a Summary of Traditional Student Elasticities.

Table 1 Summary of Traditional Student Elasticities

\begin{tabular}{|c|c|c|}
\hline $\begin{array}{l}\text { Traditional (age 18-24) } \\
\text { Student Population }\end{array}$ & Researcher(s) & Generalizable Findings \\
\hline Four-Year Population & $\begin{array}{l}\text { (Leslie \& } \\
\text { Brinkman,1987) }\end{array}$ & - Relatively inelastic \\
\hline $\begin{array}{l}\text { Two-Year Community College } \\
\text { Population }\end{array}$ & $\begin{array}{l}\text { (Leslie \& } \\
\text { Brinkman,1987) }\end{array}$ & $\begin{array}{l}\text { Elastic in comparison } \\
\text { to four-year traditional } \\
\text { populations }\end{array}$ \\
\hline Private Institution Population & (Funk, 1972) & - Relatively inelastic \\
\hline Public Institution Population & (Funk, 1972) & $\begin{array}{l}\text { Elastic in comparison } \\
\text { to private traditional }\end{array}$ \\
\hline Online Public Population & $\begin{array}{l}\text { (Byrd, Roufagalas, \& } \\
\text { Mixon, 2015) }\end{array}$ & - Highly elastic \\
\hline In Person Public Population & $\begin{array}{l}\text { (Byrd, Roufagalas, \& } \\
\text { Mixon, 2015) }\end{array}$ & - Relatively inelastic \\
\hline Lower Classmen Population & $\begin{array}{l}\text { (Bryan \& Whipple, } \\
\text { 1995) }\end{array}$ & $\begin{array}{l}\text { - Elastic compared to } \\
\text { Upperclassmen }\end{array}$ \\
\hline Upperclassmen Population & $\begin{array}{l}\text { (Bryan \& Whipple, } \\
\text { 1995) }\end{array}$ & $\begin{array}{l}\text { Inelastic compared to } \\
\text { Lower Classmen }\end{array}$ \\
\hline
\end{tabular}




\section{II.3 Models}

One of the issues facing the studied University is the fact that the setting of tuition price is not using any specific model as a determinate for the nontraditional student population. At some locations, tuition has increased each year regardless of the revenue, expense, or possible retention implications. Each year the revenue and expenses are analyzed but are not used in such a way that will create a model for establishing the equilibrium price for nontraditional students. The model, or lack thereof, is being used to determine the the nontraditional rate for students. Although the revenue and expenses are analyzed, a method of incorporating the revenue, expenses, persistence, instructional method, demographics, student type, and funding sources must be developed as part of a pricing model. The model used (or lack thereof) by the University is not a sustainable model, and at some point, the University may price itself out of the market with regard to tuition pricing, miss opportunities for increases in tuition pricing ensuring profit maximization, or may negatively impact nontraditional student persistence. Although economic conditions will certainly impact persistence, this study seeks to research increased tuition effect on persistence probability in a static environment considering differentiated population segments and demographics as a small portion of building a differentiated pricing model for nontraditional student populations.

Tuition pricing models must include expense and revenue inputs so that an evaluation can be completed based upon projected net earnings (Bryan \& Whipple, 1995) coupled with tuition elasticity. With varying expenses, University administrators may find it prudent to differentiate in their tuition pricing strategy for nontraditional students to better reflect the expenses and revenue of each sector including instructional method without significantly impacting persistence. Additionally, the effect of the tuition pricing on persistence must be evaluated specifically with demographics in mind. Is the pricing sufficient to cover cost? Most likely, yes. 
Is the pricing model so high that it causes attrition or causes certain demographics of nontraditional students not to persist? That is to be determined.

Much of the current literature focuses on financial aid as a factor in determining a tuition pricing model. "Analysts have argued that ready access to Pell Grants and federal loans prop up college prices." (Parry, 2012) This may be true for the traditional on campus student population; however, it has yet to be studied strictly in the nontraditional online population, which, at this University tends to have a higher average age (35+), more military personnel, and students that attend the institution part-time while they are employed. Should the tuition pricing model focus on financial aid, since the model is shifting from less government funding to more individual funding (Fethke, 2014)? Although financial aid can certainly add a variable worth investigating for this research, it will not be a focus of this model and research as the University studied does not offer institutional financial aid to the nontraditional student population.

This empirical case study will focus on the theory of elasticity applied to tuition referring to this as Tuition Elasticity Theory coupled with segmented pricing strategies focusing on the tuition increase or decrease effect on specific population segments: specifically nontraditional students by instructional method, gender, military status, and race (as reported to IPEDS). This theory applied to the analysis of two distinct segments should yield a coefficient predicting probability of persistence based on the data observed and analyzed. Additionally, the application to other nontraditional student populations by demographic should yield distinct coefficients predicting the probability of persistence relative to a tuition increase. These coefficients can be utilized in further research to estimate elasticities adding data points for different segments to Tuition Elasticity Theory. 
Figure 1 Shifting Focus from Traditional Students to Nontraditional Students

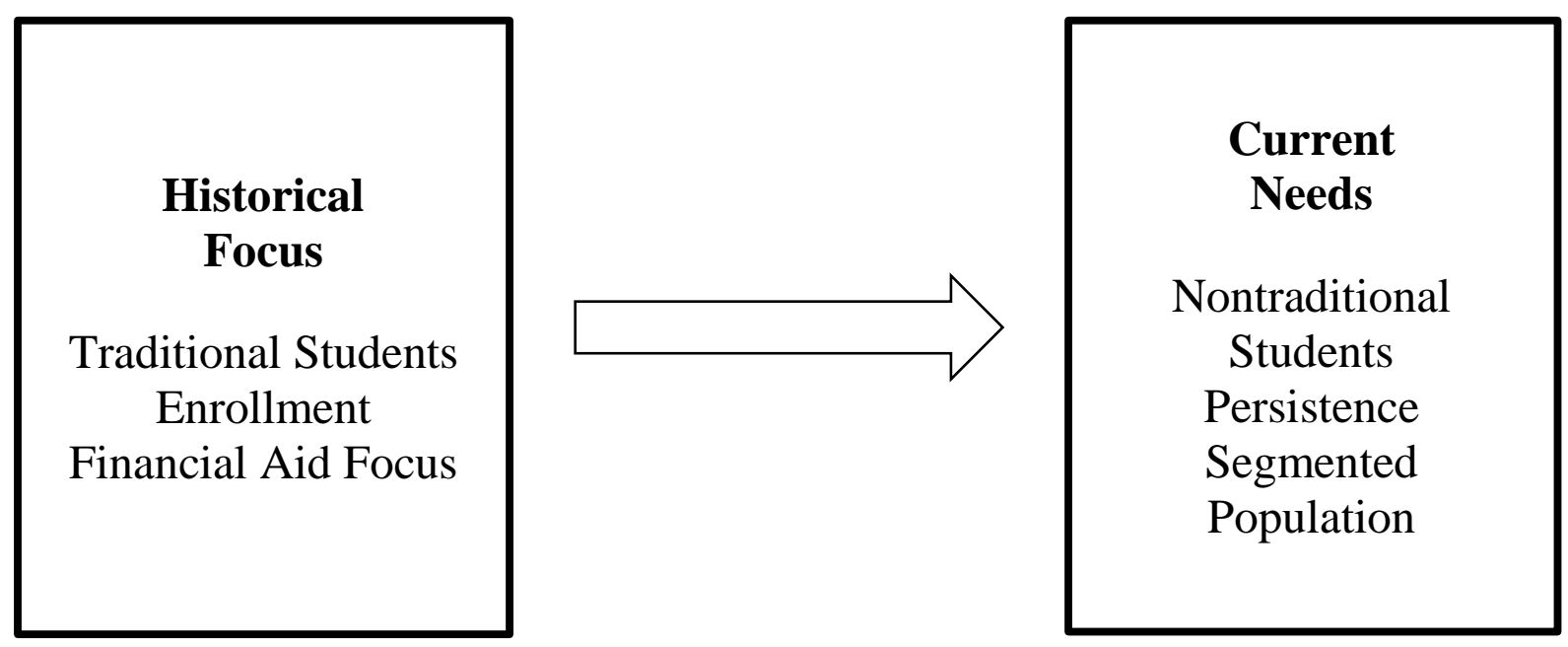

Multiple models are recognized in academia as methods for tuition price modeling. Several models reviewed for the purpose of beginning the research and synthesis for tuition pricing models suggest that there are quite a few ways to develop tuition pricing models depending on the variables that the institution wants to consider for tuition elasticity purposes (See Table 2.3 Models in Tuition Pricing). The Equilibrium Model of the College Market suggests that there are multiple inputs to tuition price modeling including ability to pay, preferences, application cost, scores, and essays (Choa, 2014). The No Financial Aid pricing model described by Parry explores setting tuition so low that students do not have to borrow to attend but, rather, students pay monthly prices similar to a car payment to take as many classes as possible. (Parry, 2012). The HH LL Model suggests that price differentiation should occur between economic classes to enable lower income students to be able to receive more aid, thus increasing affordability and enrollment (Curs \& Singell, 2010). Another model considers competitive tuition price modeling taking into consideration the human capital input (Rothschild \& White, 1995) and yet another suggests differentiation by major as a variable of the tuition pricing model (Shin \& Milton, 2008). While these models are helpful for predicting enrollment, 
revenue and expenses, these models do not take into consideration the effect on enrollment, retention, or persistence, nor specifically take into consideration nontraditional students.

Table 2 Models in Tuition Pricing

\begin{tabular}{|l|l|}
\hline \multicolumn{1}{|c|}{ Model } & \multicolumn{1}{c|}{ Description } \\
\hline $\begin{array}{l}\text { The Equilibrium Model of the } \\
\text { College Market }\end{array}$ & $\begin{array}{l}\text { Tuition pricing is dependent on abilities, preferences, } \\
\text { application cost, scores, and essays }\end{array}$ \\
\hline $\begin{array}{l}\text { No Financial Aid Pricing } \\
\text { Model }\end{array}$ & Reduce tuition based on no offering of financial aid \\
\hline HH LL Model & Tuition pricing differentiation by economic sector \\
\hline $\begin{array}{l}\text { Differentiation by Major } \\
\text { Model }\end{array}$ & Tuition pricing differentiation by major \\
\hline $\begin{array}{l}\text { Tuition Elasticity and Net } \\
\text { Earning Projections (TENEP) }\end{array}$ & $\begin{array}{l}\text { Tuition pricing model based on retention and earnings } \\
\text { projections }\end{array}$ \\
\hline
\end{tabular}

The concept of enrollment is often considered the gold standard for developing tuition pricing models; however, including only enrollment in the model neglects the bigger picture of retention and persistence as a needed influence on tuition pricing models. The concept of retention/persistence must be considered in higher education when developing pricing models for tuition. Retention is often used as a term to describe the percentage of traditional full-time students taking courses in a residential program who are retained until graduation either at a four-year or six-year reporting interval. Persistence is a year to year figure that is used to describe the percentage of students (nontraditional students) that continue year to year in their program of study without regard to a graduation timeline. These figures are important to administrators in education as it helps them estimate revenue and expenses more accurately based upon those students that will be returning (St. John, 1990).

Bryan and Whipple suggest that the elasticity of the tuition will vary from lower classmen to upperclassmen as the risk associated with transferring increases (Bryan \& Whipple, 1995). Certainly, there are other variables that may affect retention and persistence as 
nontraditional students typically are older (average age of 35), part-time or full-time employed or have military obligations and/or families. The demographics of the nontraditional student population may influence the decision of the student to enroll just as the tuition pricing model influences the decision.

\section{II.3.1 The Tuition Elasticity and Net Earning Projections (TENEP) model}

The Tuition Elasticity and Net Earning Projections (TENEP) model, shown in Figure 2.3, is a tuition pricing model that begins to explore the effects of retention as it relates to the traditional students taking classes on campus (Bryan \& Whipple, 1995). Using this model, tuition pricing models are explored, demonstrating the effects of different tuition pricing models on retention. While this model does not specifically address the nontraditional student population, its usefulness could be applied to the nontraditional population with relative accuracy with an established rate of elasticity for nontraditional students. As the model is applied to retention, it can be assumed that this would also apply to persistence.

Bryan and Whipple state that, "When tuition is increased, three of the possible scenarios for the current student population are: (1) high retention and a major tuition revenue increase; (2) moderate retention and a net increase in tuition revenues; or (3) low retention and a severe tuition revenue decrease." Focusing on the TENEP model, Bryan and Whipple completed an analysis on various tuition rates and enrollment numbers hypothetically estimating elasticity functions. The resulting research found that the retention rates were negatively impacted as tuition rates were increased (Bryan \& Whipple, 1995). 
Figure 2 Portion of the TENEP MODEL

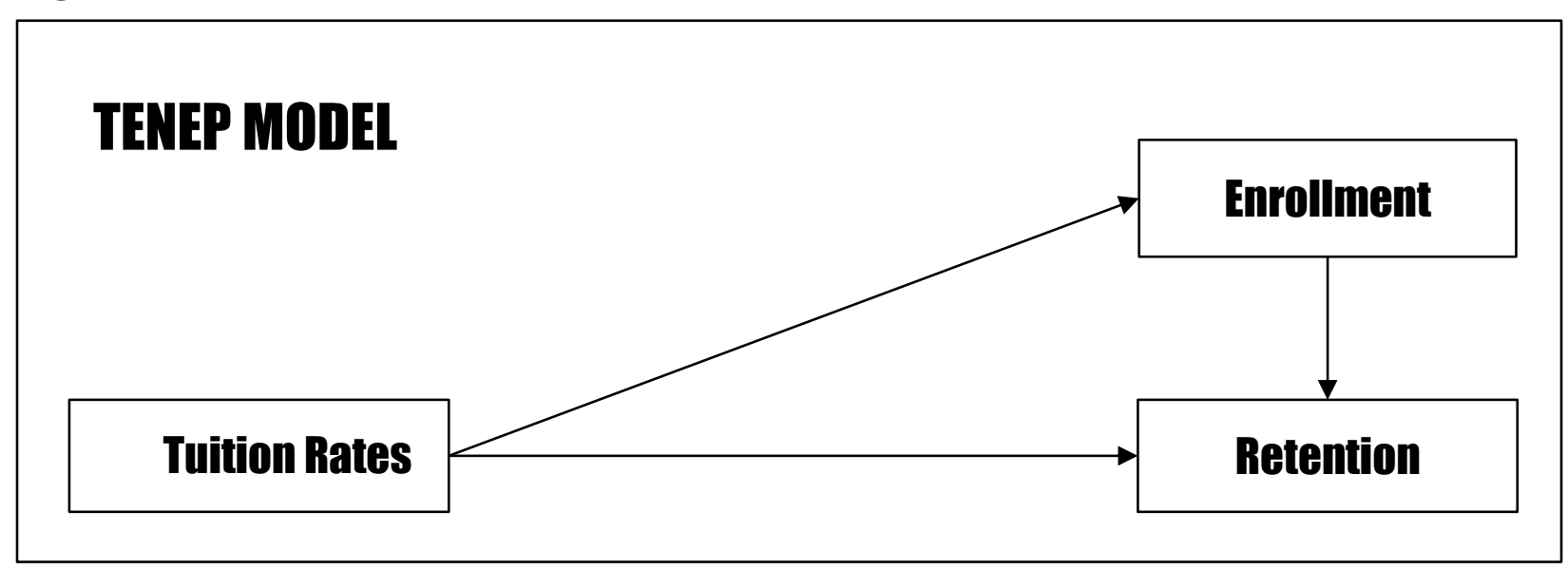

Adapted from Bryan \& Whipple, 1995

When establishing a tuition pricing model, "Price determination is a difficult decision; one that should establish a tuition that retains current students, attracts new students, and provides adequate revenues to cover costs," (Bryan \& Whipple, 1995). Persistence rates will vary by student demographics but will be affected by the tuition pricing models no matter the model chosen. Models must be carefully constructed to take into consideration the persistence rates rather than just the enrollment rates as students that do not persist become part of the attrition rate resulting in lost tuition dollars for the University. Tuition pricing models that focus on enrollment, focus simply on those students that enroll for one semester. The TENEP model does not take into consideration those that do not persist. This case study seeks to analyze the persistence rates in place of enrollment using a portion of the TENEP model to study the effect of tuition dollars on nontraditional student populations. 


\section{RESEARCH METHODOLOGY AND DESIGN}

This quantitative empirical case study uses data from a private, nonprofit university in the SACSCOC regional area with four campuses with differentiated tuition rates serving nontraditional students. Data is secondary, non-identifying data from the student information system of the private, nonprofit university.

The effects of a tuition increase on persistence of nontraditional students is measured using the following variables from the fields in the student information system; tuition increase by percent; absolute tuition per credit hour; rates by campus; enrollment history for each student used to calculate persistence for each academic year; age bracketed by traditional and nontraditional; gender male or female; race as defined by IPEDS; and military status including active duty, former military, national guard reserves, dependent, civilian, or unknown. This study uses the TENEP model studying persistence rates in place of enrollment as the dependent variable as a modification of the tuition pricing model to work toward establishing a tuition pricing model that focuses on retaining nontraditional students. This case study will not address the net earnings portion of the TENEP model (expenses and revenues) as access to budgetary data was not openly available for use at the time of this study.

\section{III.1 Method Analysis}

A fixed effects linear regression analysis of the effect of tuition on nontraditional student persistence over the last five academic years and persistence periods of four years, moderated by demographics (online or face-to-face, age, military status, gender, and race) is used to determine if a model that challenges the current tuition pricing model focusing on enrollment and financial aid should shift to a model of persistence of segmented nontraditional student populations. 


\section{III.2 Variance Model and Theory}

A variance model was chosen with the independent variable construct of tuition price increase percent, moderated by student demographics including instructional method (online or face-to-face), gender, race, and military status to allow for exploration of the effect of tuition on nontraditional student persistence as the dependent variable. A process model was not selected as the sequence of events is not in question.

Literature has shown that tuition pricing models affect enrollment with higher tuition prices traditionally leading to lower enrollment but not necessarily disproportionately. Unfortunately, in this sector of research most of the research is conducted at public institutions utilizing aggregated data or survey data; however, the research has included liberal arts higher education institutions resulting in some ability to use results with private liberal arts higher education institutions (Hemelt \& Marcotte, 2011). This research leads to the questions:

- Does the same decline occur for private higher education institutions?

- Does tuition affect retention and persistence rin the same way?

- Does empirical student level data yield more reliable and valid results than aggregate national databases and survey data?

Tuition pricing models form the basis for how higher education institutions establish tuition rates based on the Theory of Tuition Elasticity. Nontraditional student persistence is the percentage of nontraditional students who decide to continue their education with the higher education institution year after year. Student demographics include the age of the student (traditional or nontraditional age student), gender of the population, race of the population, location and instructional method of the student, veteran status of the student, and active duty status of the student. As the shift of the financial burden is shifting from the taxpayer to the 
student (Fethke, 2014) and this University does not utilize institutional financial aid for the nontraditional student population, it was an easy decision to exclude financial aid as a moderator or construct for this study. As revenues and expenses were not available for use at the time of this study, it was also an easy decision to focus on the persistence and tuition price constructs. The literature synthesis highlighted the lack of uniformity in tuition pricing models and the large variances in the major contributors including enrollment, revenue, expenses, financial aid, student demographics, and student types. The literature synthesis showed that there was not a model that focused on student persistence as a major consideration in tuition pricing models as it pertained to tuition elasticity. This variance model will focus on highlighting the effects of tuition increases on nontraditional student persistence moderated by the student demographics to build models and to strengthen the literature in this area of research building upon existing models (TENEP) and theories. 


\section{DATA COLLECTION AND ANALYSIS AND RESULTS}

\section{IV.1 Data Collection}

This study uses five years of enrollment history data from the years 2013 through 2017 with information contained at the student level obtained from the student information system of the University studied. For each observation in the data, the student persistence from one academic year to the next is calculated using the term enrollment history to determine in the student persisted the following academic year as evidenced by enrollment in at least one term during that following academic year. This simplified approach considers that various campuses have different term and semester structures and allows the study to ignore the variances in structure and focus on persistence by academic year. Two models were tested utilizing persistence as a dichotomous variable (persisted $11=\mathrm{yes}, 0=\mathrm{no}$ ) and as a continuous variable (persistedterms) to determine which model had the highest explained variance by the model.

\section{IV.2 Data Description}

The researcher gathered one data set from the student information system of the University including full enrollment history for the four campuses by each term or semester by student. The non-identifying data set includes demographic information including age, gender, race, ethnicity, campus, instructional method, military status, military branch at the student level. For the sake of this study, the age was treated as time invariant and calculated as of the date of the receipt of the student file. The age was used to split the file into traditional students $(<25$ years of age) and nontraditional students ( $>24$ years of age) to account for the age construct. Important for this analysis is that tuition rates and changes were across campuses and years. Thus there is variation in the key study variable (change in tuition) by year and campus. 


\section{IV.3 Data Analysis Strategy}

Data was cleansed and appropriate quantitative techniques were followed to identify and remove null records such as those students who had enrolled but dropped or withdrew before completing any coursework, students that had graduated, and those students who had not yet enrolled in at least two academic years for the purposes of being able to observe persistence. Those students who were observed to have not persisted were removed after the academic year of observing non-persistence. The data set contained 8,805 face-to-face observations for nontraditional students and 2,296 online observations for nontraditional students with 7,419 observations for nontraditional students between the ages of 25-38, 3,505 observations for nontraditional students between the ages of 39-66, and 177 observations for nontraditional students over the age of 66 . Females accounted for 4,265 nontraditional student observations while males accounted for 6,604 nontraditional student observations and 232 nontraditional student observations choosing to not disclose gender. Of the students in the data set 5,755 nontraditional student observations were civilians, 2,696 active duty, 1,892 former military, 391 national guard or reserves, 326 dependents (spouse or child), and 41 unknown service members (categorized by use of tuition assistance or veterans assistance). Of the students in the data set, 3,478 nontraditional student observations were classified as White, 1,797 as African American/Black, 168 as Asian, 1,355 as Hispanic, 146 as Native Hawaiian or Pacific Islander, 75 as American Indian or Alaskan Native, 167 electing 2 or more races, and 3,915 undisclosed races.

Data was organized into four persistence observation periods with 12,047 observations for 4,097 students at four campuses with differentiated pricing. Each student record contained a field entitled term enrollment history with each term of enrollment history listed in an aggregate form in one field. This information had to be parsed into individual term enrollment history for 
each term in order to allow the persistence field to be calculated based on the number of terms enrolled each academic year. In Model 1, if the student registered for at least one term during the following academic year, the student was coded with a 1 for persistence utilizing the variable persistedl. If the student did not register for at least one term during the following academic year, the student was coded with a 0 for persistence. This created four different observation periods for students for persistence. In Model 2, if the student registered for at least one term during the following academic year, the students enrolled terms for that following academic year was used to populate the variable persistedterms. As tuition prices were only changed at the beginning of each academic year (fall), the effect of tuition prices on persistence was studied academic year to academic year rather than term to term or semester to semester for uniformity.

\section{IV.4 Hypotheses Testing}

The effect of tuition prices on nontraditional student persistence is studied utilizing a portion of the research model, adapted from the TENEP model. Figure 4.4, depicts the over all model and hypotheses developed for this study based upon research of the Tuition Elasticity Theory and applicable Pricing Models. 
Figure 3 Conceptual Model for Constructs and Hypotheses

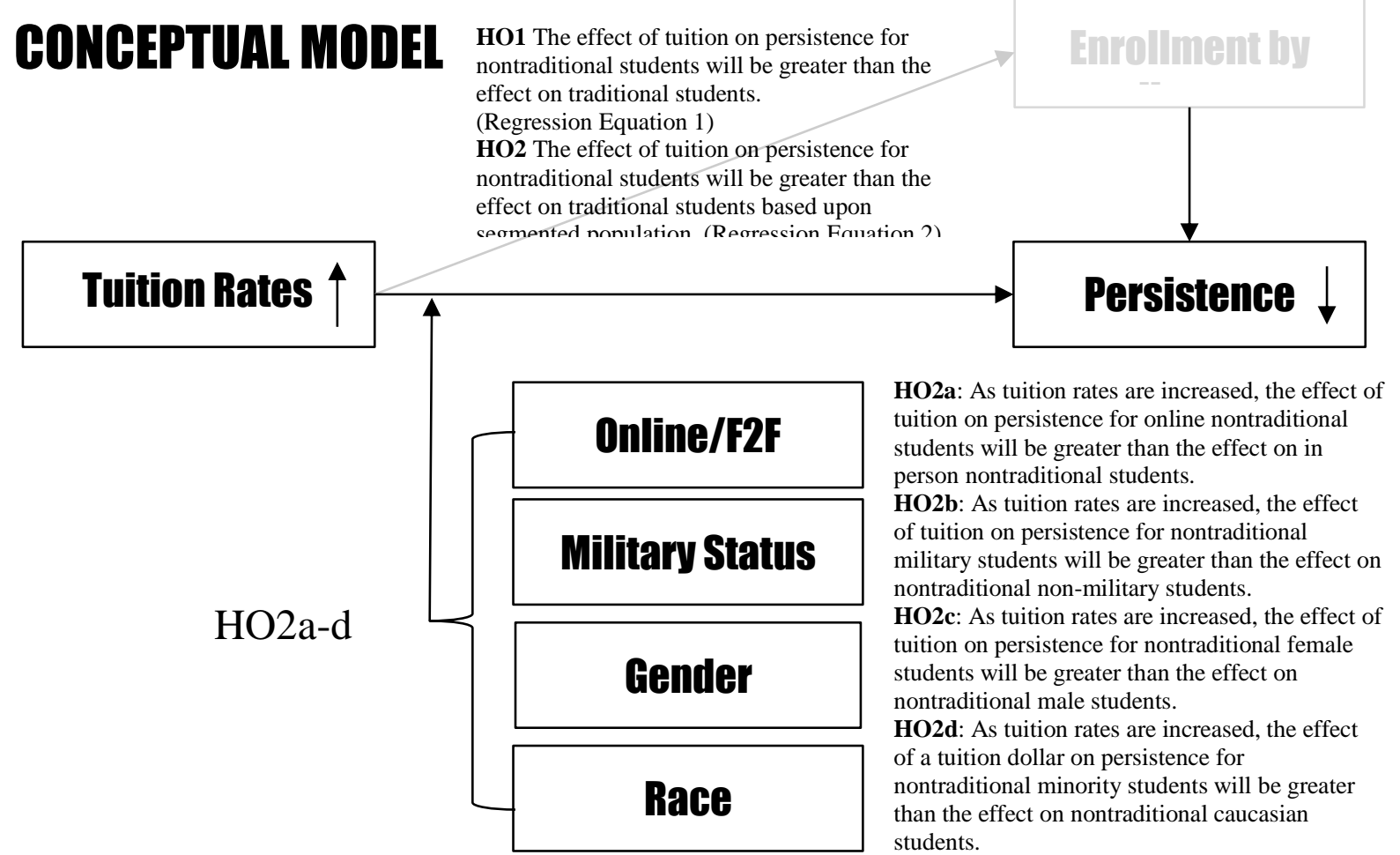

\section{IV.4.1 Tuition Effects on Persistence for Nontraditional Students}

Price Elasticity Theory of Demand is to first "show (1) how elasticity changes along the function and (2) how these elasticities are related to total expenditure at alternate prices and quantities" (Houck, 1967) and thus this theory can be applied to higher education as tuition and enrollment are studied. The Tuition Elasticity Theory is calculated by dividing a percentage change in enrollment by the percentage change in tuition. As each resulting coefficient from the change in tuition dollars will result in some effect on the probability of persistence, it is rational to assume that different populations will respond to tuition price changes differently. In this data set the average age is 38 among the nontraditional students. In 1987, Leslie and Brinkman noted the elastic nature of two-year higher education institutions as compared to four-year institutions with traditional aged populations. These institutions, such as community colleges and technical 
schools, target and are more appealing to lower income and older populations (Leslie \& Brinkman,1987). Using this research that states that older populations and lower income populations appear to be more elastic than traditional aged populations coupled with the average age of 38 of this data set, resulted in the hypothesis:

HO1 The effect of tuition on persistence for nontraditional students will be greater than the effect on traditional students.

\section{IV.4.2 Tuition Effects on Persistence for Nontraditional Online Students}

With Price Elasticity Theory of Demand establishing that price increases can result in varied decisions, additional research to establish the effects of online versus face-to-face instructional methods was necessary. In 2015, Byrd, Roufagalas, \& Mixon noted that in the higher education industry, public online institutions with traditional aged populations were highly elastic as compared to public face-to-face instruction at institutions with traditional aged populations. With this observation made of traditional aged populations combined with the suggested research that older populations are also more elastic than younger populations, the following hypothesis resulted:

HO2a: As tuition rates are increased, the effect of tuition on persistence for online nontraditional students will be greater than the effect on nontraditional face to face students.

\section{IV.4.3 Tuition Effects on Persistence for Nontraditional Military Students}

In the data set studied, military pay grades ranged from E1-E9, O1-O8, and W1-W5. Of the nontraditional population in this data set, $62.58 \%$ of the military population ranked as an E4, E5, or E6. According to the 2018 "Base Pay PDF" published by the U.S. Department of Homeland Security, the following pay ranges apply to these pay grades depending on years of service: 
Table 3 Selected Military Pay Grades and Base Ranges per Month

\begin{tabular}{|c|c|c|c|c|c|}
\hline \multicolumn{2}{|c|}{ E4 (20.91\%) } & \multicolumn{2}{c|}{ E5 (23.35\%) } & \multicolumn{2}{c|}{ E6 (18.32\%) } \\
\hline Low & High & Low & High & Low & High \\
\hline$\$ 2,139.00$ & $\$ 2,596.50$ & $\$ 2,332.80$ & $\$ 3,310.50$ & $\$ 2,546.40$ & $\$ 3,944.10$ \\
\hline
\end{tabular}

Intuitive rationale supports that as prices increase, fewer students will be able to afford the higher tuition rates. In the nontraditonal military student population, it is reasonable to assume that this rationale would apply because the majority of this population fall into a lower income category. Utilizing previous research supporting higher elasticity with lower income populations with the knowledge of the limited tuition assistance provided by the military, rationale would support the hypothesis:

HO2b: As tuition rates are increased, the effect of tuition on persistence for nontraditional military students will be greater than the effect on nontraditional nonmilitary students.

\section{IV.4.4 Tuition Effects on Persistence for Nontraditional Female Students}

According to the U.S. Census Bureau (2016a), in 2016 women earned \$0.805 cents to every dollar of male earnings. With almost $20 \%$ less income than males, it can be assumed that the expendable income of females is less than males; thus, rationale would support that females would be more likely to fall in the category of lower income than males and the following hypothesis would apply:

HO2c: As tuition rates are increased, the effect of tuition on persistence for nontraditional female students will be greater than the effect on nontraditional male students. 


\section{IV.4.5 Tuition Effects on Persistence for Nontraditional Minority Students}

In 2016, the U.S. Census published, Real Median Household Income by Race and Hispanic Origin: 1967 to 2016 which showed a national median salary of $\$ 59,039$ of all races. Hispanic and Black races were shown with median incomes less than the national median salary of $\$ 47,675$ and $\$ 39,490$ respectively (U.S. Census Bureau, 2016b). Additionally, Cameron and Heckman (2001) acknowledge the racial and ethnic disparities of enrollment in post-secondary education which may or may not be caused by financial disparities. With the two majority minorities (totaling $24.45 \%$ of the $29.23 \%$ minorities in the data set) in this data set being Hispanic (9.12\%) and Black or African American (15.33\%), rationale would support that minorities, with typically lower than national median wages than Caucasians $\$ 65,041$-especially Hispanic and African American or Black races would have less access to financial resources and family support (Semega, Fontenot, \& Kollar, 2017) and thus:

HO2d: As tuition rates are increased, the effect of tuition on persistence for nontraditional minority students will be greater than the effect on nontraditional Caucasian students. 


\section{FINDINGS}

This quantitative study focuses on statistical significance where the focus will be on explained $p$ value with a set alpha of .05 or less using the linear regression equation models to test the two sets of hypotheses with student level data provided by a private nonprofit higher education institution.

\section{V.1 Hypotheses and Results}

A summary of the outcomes from each hypothesis suggests that the model and contributions to practice and theory are partially supported by the research and the research can be used as a helpful guide for higher education institutions and customer relationship management softwares targeting higher education institutions.

The research suggests the following:

- Cross-price elasticity suggest that this institution is considered a substitute good for other institutions

- For every 1 percent increase in tuition, nontraditional online students are decreasing their persistence by 0.9 percent

- Tuition increases result in nontraditional students persisting less than traditional students

- Tuition increases result in nontraditional online students persisting less than nontraditional face-to-face students

- Tuition increases result in nontraditional female students persisting less than nontraditional male students

- Tuition increases result in nontraditional minority students persisting less than nontraditional Caucasian students 
Table 4 Summary of Hypotheses and Results

\begin{tabular}{|c|c|c|c|c|}
\hline Hypotheses & \multicolumn{2}{|c|}{ Findings } & Measures \& Tests & Implications \\
\hline $\begin{array}{l}\text { (HO1) The effect a change } \\
\text { in tuition on persistence } \\
\text { for nontraditional students } \\
\text { will be greater than the } \\
\text { effect on traditional } \\
\text { students. }\end{array}$ & $\begin{array}{l}\text { Tuition } \\
\text { Nontraditional } \\
\text { Online } \\
\text { Minority } \\
\text { Nontraditional x } \\
\text { Tuition \% } \\
\text { Online x Tuition \% }\end{array}$ & $\begin{array}{l}\mathbf{0 . 0 2 0 1} * * \\
-0.0165 \\
0.0919 * * \\
-0.2313 * * \\
\mathbf{- 0 . 0 1 3 9 *} \\
-0.0128 * *\end{array}$ & $\begin{array}{l}\text { Not Supported/ } \\
\text { Significant } \\
|0.0201|>|0.0062|\end{array}$ & $\begin{array}{l}\text { For every } 1 \text { percent increase in } \\
\text { tuition, all students are } \\
\text { increasing their persistence by } \\
2.01 \text { percent, but nontraditional } \\
\text { students are only increasing } \\
\text { their persistence by }(.02-.014) \\
\text { or by } 0.62 \text { percent, persisting } \\
\text { less than traditional students. }\end{array}$ \\
\hline $\begin{array}{l}\text { (HO2a) As tuition rates are } \\
\text { increased,the effect of a } \\
\text { tuition on persistence for } \\
\text { online nontraditional } \\
\text { students will be greater } \\
\text { than the effect on } \\
\text { nontraditional face-to-face } \\
\text { students. }\end{array}$ & $\begin{array}{l}\text { If nontraditional: } \\
\text { Tuition } \\
\text { Online } \\
\text { Online x Tuition \% }\end{array}$ & $\begin{array}{c}\mathbf{0 . 0 0 5} \\
0.103 * * \\
\mathbf{- 0 . 0 1 4}^{* *}\end{array}$ & $\begin{array}{l}\text { Supported/ } \\
\text { Significant } \\
|0.005|<|-0.009|\end{array}$ & $\begin{array}{l}\text { For every } 1 \text { percent increase in } \\
\text { tuition, nontraditional online } \\
\text { students are decreasing their } \\
\text { persistence by } 0.9 \text { percent, } \\
\text { persisting less than face-to-face } \\
\text { students. }\end{array}$ \\
\hline $\begin{array}{l}\text { (HO2b) As tuition rates are } \\
\text { increased, the effect a } \\
\text { change in tuition on } \\
\text { persistence for } \\
\text { nontraditional military } \\
\text { students will be greater } \\
\text { than the effect on } \\
\text { nontradititional } \\
\text { nonmilitary students. }\end{array}$ & $\begin{array}{l}\text { If nontraditional: } \\
\text { Tuition } \\
\text { Military } \\
\text { Military x Tuition \% }\end{array}$ & $\begin{array}{r}\mathbf{0 . 0 0 5} \\
-0.005 \\
\mathbf{0 . 0 0 2}\end{array}$ & $\begin{array}{l}\text { Supported/ } \\
\text { No Significance } \\
|0.005|<|0.007|\end{array}$ & $\begin{array}{l}\text { For every } 1 \text { percent increase in } \\
\text { tuition, nontraditional military } \\
\text { students are increasing their } \\
\text { persistence by } 0.7 \text { percent, } \\
\text { persisting more than } \\
\text { nontraditional nonmilitary } \\
\text { students. }\end{array}$ \\
\hline $\begin{array}{l}\text { (HO2c) As tuition rates are } \\
\text { increased, the effect a } \\
\text { change in tuition on } \\
\text { persistence for } \\
\text { nontraditional female } \\
\text { students will be greater } \\
\text { than the effect on } \\
\text { nontraditional male } \\
\text { students. }\end{array}$ & $\begin{array}{l}\text { If nontraditional: } \\
\text { Tuition } \\
\text { Female } \\
\text { Female x Tuition \% }\end{array}$ & $\begin{array}{r}\mathbf{0 . 0 0 5} \\
-0.006 \\
\mathbf{- 0 . 0 0 1}\end{array}$ & $\begin{array}{l}\text { Not Supported/ } \\
\text { No Significance } \\
|0.005|>|0.004|\end{array}$ & $\begin{array}{l}\text { For every } 1 \text { percent increase in } \\
\text { tuition, nontraditional female } \\
\text { students are increasing their } \\
\text { persistence by } 0.4 \text { percent, } \\
\text { persisting less than } \\
\text { nontraditional male students. }\end{array}$ \\
\hline $\begin{array}{l}\text { (HO2d) As tuition rates are } \\
\text { increased, the effect a } \\
\text { change in tuition on } \\
\text { persistence for } \\
\text { nontraditional minority } \\
\text { students will be greater } \\
\text { than the effect on } \\
\text { nontraditional Caucasian } \\
\text { students. }\end{array}$ & $\begin{array}{l}\text { If nontraditional: } \\
\text { Tuition } \\
\text { Minority } \\
\text { Race Not Disclosed } \\
\text { Minority x Tuition \% } \\
\text { Race Not Disclosed } \\
\text { x Tuition \% }\end{array}$ & $\begin{array}{l}\mathbf{0 . 0 0 5} \\
0.004 \\
-0.235^{* *} \\
\\
\mathbf{- 0 . 0 0 4} \\
-0.001\end{array}$ & $\begin{array}{l}\text { Not Supported/ } \\
\text { No Significance } \\
|0.005|>|0.001| \\
\text { Significance was found with } \\
\text { undisclosed minority status. }\end{array}$ & $\begin{array}{l}\text { For every } 1 \text { percent increase in } \\
\text { tuition, nontraditional minority } \\
\text { students are increasing their } \\
\text { persistence by } 0.1 \text { percent, } \\
\text { persisting less than } \\
\text { nontraditional Caucasian } \\
\text { students. }\end{array}$ \\
\hline
\end{tabular}

$* .05, * * .01$ alpha indicates significance

\section{V.2 Linear Regression Model Selection and Justification}

Two models were tested utilizing persistence as a dichotomous variable (persisted1

$1=$ yes, $0=$ no) and as a continuous variable (persistedterms) to determine which model had the

highest explained variance (R2) and lowest errors (Root MSE) by the model. The dichotomous

dependent variable provided a higher explained variance that tells us that $25.04 \%$ of the variation 
in probability of student populations persisting can be explained by variation in the independent variables taken together and the $26.23 \%$ of the variation in probability of nontraditional student populations persisting can be explained by the variation in the independent variables taken together. Lower errors as shown in the Root MSE for all hypotheses also resulted from the use of the dichotomous variable as discussed further in the findings. A summary of the variables studied are listed in Table 5.2, Summary of Mean Variables.

Table 5 Summary of Mean Variables

\begin{tabular}{|c|c|c|c|c|}
\hline & Full Sample & $\begin{array}{l}\text { Traditional } \\
\text { (18-24 yrs) }\end{array}$ & $\begin{array}{c}\text { NonTraditional } \\
(25+y r s)\end{array}$ & $p$ value \\
\hline $\mathbf{N}$ by observation & 12,496 & 1,395 & 11,101 & \\
\hline \multicolumn{5}{|l|}{ Variable Label } \\
\hline Share Persisted & 0.580 & 0.612 & 0.576 & 0.0112 \\
\hline Mean Terms Persisted/AY ${ }^{* *}$ & 1.607 & 1.5309 & 1.6161 & 0.0727 \\
\hline Mean Tuition per Credit Hour & $\$ 289.92$ & $\$ 283.84$ & $\$ 290.68$ & 0.0002 \\
\hline Mean Tuition \% Increase & 1.857 & 1.466 & 1.906 & 0.0000 \\
\hline Share Online & 0.209 & 0.224 & 0.207 & 0.1286 \\
\hline Share Military & 0.493 & 0.375 & 0.508 & 0.0000 \\
\hline Share Female & 0.390 & 0.438 & 0.384 & 0.0001 \\
\hline Share Reporting Minority & 0.292 & 0.354 & 0.285 & 0.6028 \\
\hline Share Race Not Disclosed & 0.440 & 0.232 & 0.466 & 0.0000 \\
\hline \multicolumn{5}{|l|}{ N by Year (Controls) } \\
\hline 2015 & 1,985 & 137 & 1,848 & \\
\hline 2016 & 2,864 & 264 & 2,600 & \\
\hline 2017 & 3,703 & 454 & 3,249 & \\
\hline 2018 & 3,944 & 540 & 3,404 & \\
\hline State Tuition \% Increase (Control) & $4.140 \%$ & $4.274 \%$ & $4.125 \%$ & 0.0000 \\
\hline
\end{tabular}




\section{V.3 Effect of Tuition Increase on Nontraditional Persistence}

HO1 The effect of tuition increase on persistence for nontraditional students will be greater than the effect on traditional students.

Two models were tested utilizing persistence as a dichotomous variable (persisted 1 $1=$ yes, $0=$ no) and as a continuous variable (persistedterms) to determine which model had the highest explained variance and lowest error. The dichotomous variable provided a higher explained variance for $\mathrm{HO} 1$ resulting in an $\mathrm{R} 2$ of $25.04 \%$ explained variance as opposed to the continuous variable with an R2 of $10.63 \%$ explained variance. For the two models the errors were higher in Model 2 with a root MSE of 1.69 as compared to a root MSE of 0.427 in Model 1. A control was entered into the model controlling for the University's state four-year private school tuition average price increase; however, as this introduced multicollinearity the results were omitted due to collinearity and thus the model was run without the control variable. Model 1 was utilized to observe through a linear regression model that the effect of a 1 percent tuition increase on persistence for all students increased their persistence by 2.01 percent, but nontraditional students only increased their persistence by (.02-.014) or by 0.62 percent, persisting less than traditional students. An alpha of .025 indicates this finding is of statistical significance; however, because of the unique nature of the finding, the hypothesis would be considered not supported even though nontraditional student persist less than traditional students. Table 5.3, Summary of Persistence, contains a summary of the findings for the linear regression equation (footnote) utilized to estimate the effect of tuition increases on overall persistence. 
Table 6 Summary of Persistence

\begin{tabular}{|c|c|c|c|}
\hline & Coefficient & Robust Std Errors & $p$-value \\
\hline \multicolumn{4}{|l|}{ Variable } \\
\hline Tuition \% Increase & 0.0201 & 0.007 & 0.00 \\
\hline \multicolumn{4}{|l|}{ Demographic } \\
\hline Nontraditional & -0.0165 & 0.019 & 0.38 \\
\hline Online & 0.0919 & 0.023 & 0.00 \\
\hline Military & -0.0032 & 0.009 & 0.72 \\
\hline Female & 0.0051 & 0.012 & 0.67 \\
\hline Minority Reported & 0.0030 & 0.017 & 0.86 \\
\hline Race Not Disclosed & -0.2313 & 0.016 & 0.00 \\
\hline \multicolumn{4}{|l|}{ Tuition Interaction Terms } \\
\hline Nontraditional $x$ Tuition \% Increase & -0.0139 & 0.006 & 0.03 \\
\hline Online $x$ Tuition \% Increase & -0.0128 & 0.005 & 0.01 \\
\hline Military x Tuition \% Increase & 0.0018 & 0.002 & 0.47 \\
\hline Female $x$ Tuition $\%$ Increase & -0.0029 & 0.003 & 0.40 \\
\hline Minority Reported $x$ Tuition \% Increase & -0.0044 & 0.005 & 0.32 \\
\hline Race Not Disclosed $x$ Tuition \% Increase & -0.0006 & 0.005 & 0.90 \\
\hline \multicolumn{4}{|l|}{ By Year } \\
\hline 2016 & -0.3410 & 0.009 & 0.00 \\
\hline 2017 & -0.4836 & 0.009 & 0.00 \\
\hline 2018 & -0.6909 & 0.009 & 0.00 \\
\hline Constant & 1.1183 & 0.021 & 0.00 \\
\hline
\end{tabular}

(HO1) Persistence $=\beta 0+\beta 1$ Tuitionpercent $+\beta 2$ Nontrational $+\beta 3$ Online $+\beta 4$ Military $+\beta 5$ Gender $+\beta 6$ Race $+\beta 7$ (Tuitionpercent $x$ Nontraditional $)+\beta 8($ Tuitionpercent $x$ Online $)+\beta 9($ Tuitionpercent $x$ Military $)+\beta 10$ (Tuitionpercent $x$ Gender $)+\beta 11($ Tuitionpercent $x$ Race $)+\varepsilon$

\section{V.4 Effect of Tuition Increase on Nontraditional Persistence by Demographic}

A linear regression was calculated to predict persistence based on tuition prices moderated by demographics including online or face-to-face, military status, gender, and race. A significant regression equation was found $(\mathrm{F}(14,3541)=449.84, p<0.0000)$, with an $\mathrm{R}^{2}$ of 0.2623 as shown in Table 5.4, Summary of Nontraditional Persistence by Demographic with a footnote 
detailing the linear equation utilized for the research, where tuitionpercent is measured as the change in tuition price per credit hour in the observed persistence period and online1, nonmilitary 1 , and female 1 are dichotomous variables coded with $1=y e s$ and $0=$ no, and noncaucasian 2 is coded $1=y e s, 2=$ not disclosed, and $0=$ no.

Table 7 Summary of Nontraditional Persistence by Demographic

\begin{tabular}{|c|c|c|c|}
\hline & Coefficient & Robust Std Errors & $\mathrm{p}$-value \\
\hline \multicolumn{4}{|l|}{ Variable } \\
\hline Tuition \% Increase & 0.005 & 0.005 & 0.30 \\
\hline \multicolumn{4}{|l|}{ Demographic } \\
\hline Online & 0.103 & 0.025 & 0.00 \\
\hline Military & -0.005 & 0.009 & 0.56 \\
\hline Female & -0.006 & 0.013 & 0.66 \\
\hline Minority Reported & 0.004 & 0.019 & 0.85 \\
\hline Race Not Disclosed & -0.235 & 0.017 & 0.00 \\
\hline \multicolumn{4}{|l|}{ Tuition Interaction Terms } \\
\hline Online $\mathrm{x}$ Tuition $\%$ Increase & -0.014 & 0.005 & 0.01 \\
\hline Military x Tuition \% Increase & 0.002 & 0.003 & 0.44 \\
\hline Female $\mathrm{x}$ Tuition $\%$ Increase & -0.001 & 0.004 & 0.73 \\
\hline Minority Reported x Tuition \% Increase & -0.004 & 0.005 & 0.40 \\
\hline Race Not Disclosed x Tuition \% Increase & -0.001 & 0.005 & 0.89 \\
\hline \multicolumn{4}{|l|}{ By Year } \\
\hline 2016 & -0.345 & 0.010 & 0.00 \\
\hline 2017 & -0.495 & 0.010 & 0.00 \\
\hline 2018 & -0.699 & 0.009 & 0.00 \\
\hline Constant & 1.115 & 0.017 & 0.00 \\
\hline
\end{tabular}

HO2: Nontraditional Persistence $=1.149128+-.0001186$ (tuitionpercent $)+-.1280046($ online 1$)+-.5603377($ nonmilitary 1$)+-$

$.0186181($ female 1$)+-.0030993($ noncaucasian 2$)+.00056($ tuitionpercent $\mathrm{x}$ online 1$)+.0011477($ tuitionpercent $\mathrm{x}$ nonmilitary 1$)+$ .000109 (tuitionpercent $\mathrm{x}$ female1) +.0001589 (tuitionpercent $\mathrm{x}$ noncaucasian2)

Two models were tested utilizing persistence as a dichotomous variable (persisted1 $1=$ yes, $0=$ no) and as a continuous variable (persistedterms) to determine which model had the 
highest explained variance and lowest error. The dichotomous variable provided a higher explained variance for $\mathrm{HO} 2$ resulting in an $\mathrm{R} 2$ of $26.09 \%$ explained variance as opposed to the continuous variable with an R2 of $11.11 \%$ explained variance. For the two models, the errors were higher in Model 2 with a root MSE of 1.701 as compared to a root MSE of 0.4276 in Model 1. Instructional method was of significance as a predictor of persistence.

\section{V.4.1 Moderated by Online}

HO2a: As tuition rates are increased, the effect of tuition on persistence for online nontraditional students will be greater than the effect on nontraditional face-to-face students.

Model 1 was utilized to observe that for every 1 percent increase in tuition, nontraditional online students are decreasing their persistence by 0.9 percent, persisting less than face-to-face students. With an alpha of 0.01 , this finding is considered significant and supports the hypothesis.

\section{V.4.2 Moderated by Military Status}

HO2b: As tuition rates are increased, the effect of a tuition increase on persistence for nontraditional military students will be greater than the effect on nontraditional nonmilitary students.

Using Model 1, the following observation that for every 1 percent increase in tuition, nontraditional military students are increasing their persistence by 0.7 percent, persisting more than nontraditional nonmilitary students. With an alpha of 0.44 this finding is not considered significant but supports the hypothesis.

\section{V.4.3 Moderated by Gender}

HO2c: As tuition rates are increased, the effect of a tuition increase on persistence for nontraditional female students will be greater than the effect on nontraditional male students. 
Using Model 1, the following observation that For every 1 percent increase in tuition, nontraditional female students are increasing their persistence by 0.4 percent, persisting less than nontraditional male students. With an alpha of 0.55 this finding is not statistically significant and does not support the hypothesis but is directionally as expected.

\section{V.4.4 Moderated by Race}

HO2d: As tuition rates are increased, the effect of a tuition increase on persistence for nontraditional minority students will be greater than the effect on nontraditional Caucasian students.

Using Model 1, the following observation that For every 1 percent increase in tuition, nontraditional minority students are increasing their persistence by 0.1 percent, persisting less than nontraditional Caucasian students. With an alpha of 0.4550 this finding is not statistically significant and does not support the hypothesis but is directionally as expected. 


\section{DISCUSSION}

The literature review on tuition pricing for nontraditional student populations has limited studies that involve the nontraditional population of students and even fewer studies that involve actual data at the student level rather than aggregate data from known national sources or survey data using hypothetical scenarios for nontraditional populations of students. There is limited research on how to connect this data (at the student level) that was collected from traditional student populations for nontraditional students back to theory such as Tuition Elasticity Theory and Elasticity Theory. With a strong motivation to address some of these shortfalls in actual student level data over aggregated data, this empirical case study uses tuition pricing to estimate effect on the probability of persistence for the nontraditional student population further studied by demographic.

The quantitative empirical case study analyzes four persistence periods using student level data from a private, nonprofit university in the SACSCOC regional accreditation area. It used secondary data from a university with online and face-to-face campuses serving both traditional and nontraditional populations of students. This longitudinal study tracked the enrollment history of over 4,000 students over five academic years yielding over 12,000 observation points.

The findings support the generalizability that tuition price increases result in the increased probability of persisting by nontraditional students as evidenced by the coefficient of 0.0062. With an alpha of .03 , this finding is statistically significant but could be puzzling to interpret. However, a closer look at tuition comparisons from this University as compared to the State Average of four-year colleges and universities shows that the tuition increases by this University are lower than the State Average. The results of this study support that the effects of 
tuition increases on nontraditional student populations is different than traditional student populations in the undergraduate environment.

Table 8 Average Tuition Price Increase by Percent

\begin{tabular}{lcccc}
\hline Tuition Percent Average Increases & $\mathbf{2 0 1 5}$ & $\mathbf{2 0 1 6}$ & $\mathbf{2 0 1 7}$ & $\mathbf{2 0 1 8}$ \\
\hline Nontraditional & $2.08 \%$ & $1.98 \%$ & $1.94 \%$ & $1.73 \%$ \\
Traditional & $1.46 \%$ & $1.57 \%$ & $1.57 \%$ & $1.33 \%$ \\
State Average & $3.17 \%$ & $4.01 \%$ & $4.76 \%$ & Not Available \\
\hline
\end{tabular}

For every 1 percent increase in tuition, all students are increasing their persistence by 2.01 percent, but nontraditional students are only increasing their persistence by 0.62 percent, persisting less than traditional students. This is easily explained by Kim's 2010 article, “The Effect of Prices on Postsecondary Access: An Update to Heller, as he references cross-price elasticity. Cross-price elasticity refers to "When competing institutions are considered as substitutes for other institutions, the cross-price elasticity of demand for enrollment relates the percentage change in enrollment to the percentage change in the tuition charged by the competing institutions. A positive value of cross-price elasticity indicates that the education offered by one institution is considered to be a substitute for the services provided by a competing institution." (Kim, 2010). Because the University's cross-price elasticity is positive, education at the University is considered to be a substitute for the services of other educational institutions (and vice versa) thus because the average price increase is lower at the University than the State Average it is logical that the nontraditional student population would persist with increased tuition rates when the State Average is higher than the tuition increase percent at the University. Additional research in this field is discussed further weighing other options to a 
dichotomous model. It is possible that traditional age students may be behaving more like nontraditional aged students as they become employed to manage the shift in the amount of taxpayer funding [both Federal and State] to student funding of their tuition, paying more of the tuition out of their pocket (Fethke, 2014).

The findings from Model 1 were utilized to observe that for every 1 percent increase in tuition, nontraditional online students are decreasing their persistence by 0.9 percent, persisting less than nontraditional face-to-face students with an alpha of 0.01 showing a statistical significance. This finding further supports earlier research from Byrd, Roufagalas, and Mixon published in 2015 stating that online public student populations were highly elastic compared to face-to-face public student populations. This is not surprising as online offers students the choice of when to "attend" class and no longer limits where the student can attend due to geographic location or travel.

These findings regarding online nontraditional student populations allow the generalizability to be sustained across nonprofit, private institutions. These findings also support that tuition increases have a larger effect on online nontraditional student population persistence as compared to face-to-face nontraditional student populations. Furthermore, because these findings support prior research conducted with public traditional population students, the findings allow the generalizability to nontraditional students attending nonprofit private or public higher education institutions.

The findings from Model 1 were utilized to observe that for every 1 percent increase in tuition, nontraditional military students are increasing their persistence by 0.7 percent, persisting more than nontraditional nonmilitary students. With an alpha of 0.44 this finding is not considered significant; however, this finding does support the hypothesis that a tuition increase 
has a greater effect on nontraditional military student populations than nontraditional nonmilitary (civilian) student populations. This finding can be explained as nontraditional military students may be motivated by earning promotion to the next rank thus persistence of military students is higher than that of nontraditional nonmilitary students. The data set did not contain mean incomes for the nontraditional nonmilitary students, thus it is possible that the nontraditional nonmilitary students have a lower mean income than the nontraditional military populations, which according to findings by Leslie \& Brinkman in 1987 and Heller in 1997, likely impact the effect of a tuition increase on enrollment and thus can be generalized to an effect of a tuition increase on persistence. Further research is needed on military and nonmilitary nontraditional populations to establish a generalizable finding for nontraditional student populations.

The findings from Model 1 were utilized to observe that for every 1 percent increase in tuition, nontraditional female students are increasing their persistence by 0.4 percent, persisting less than nontraditional male students; however, the alpha of 0.73 indicates that this finding is not statistically significant. Because the statistic is not significant, further research should be conducted to identify other variables that contribute to the effect of gender, including income level and employment status as females are faced with familial decisions such as marriage and rearing children that can often be prioritized above higher education attainment and employment.

Using Model 1, the following observation For every 1 percent increase in tuition, nontraditional minority students are increasing their persistence by 0.1 percent, persisting less than nontraditional Caucasian students; however, the alpha of 0.85 indicates that this finding is not statistically significant alone. Without conducting additional regressions on individual races, Cameron and Heckman (2001) acknowledge, the racial and ethnic disparities of enrollment in postsecondary education; however, this focus is purely from the view of determining the sources 
of these disparities when the overwhelming evidence points to the income disparity between minorities and Caucasians, which is further evident in the findings of the U.S. Census Bureau (2016b). Cameron and Heckman (2001) went on to explain that even though it would appear that in the short term that tuition reductions and offsets would solve the issue, that it is more of an economic issue that must be addressed earlier in life. In any respect, this disparity of tuition pricing having a greater effect on minorities, warrants additional research especially in the realm of Hispanics, in light of the research by Cameron and Heckman (2001). Of notable statistical significance, those nontraditional students that did not disclose their ethnicity, for every 1 percent increase in tuition, increased their persistence by 0.4 percent, persisting less than nontraditional Caucasian students but more than nontraditional minority students.

This study can be used to begin building tuition pricing models in higher education. Although this study does not focus on higher education costs from an institutional perspective, knowing the impacts of tuition price increases on nontraditional persistence allows models to more accurately reflect the expected persistence based upon certain demographics in the nontraditional student population and allows administration to determine more accurately the impacts of various pricing models including the TENEP pricing model (Bryan \& Whipple, 1995).

To effectively utilize the data, the resulting linear regression equation can be applied to the institution studied immediately to offer a non-arbitrary way of estimating persistence among the online nontraditional population. Utilizing a spreadsheet and macros, data can be downloaded from the student information system and easily coded using the $1=$ Yes and $0=$ No coding allowing each student record an individual probability of persisting based upon the coded coefficients in the spreadsheet. The spreadsheet can then be used to predict overall persistence 
and enrollment at a campus or programmatic level. The equation can be modified with updated coefficients as additional studies to identify additional constructs are completed on the trending populations to achieve statistical significance and practice applicability.

Utilizing this data, the institution studied can price nontraditional tuition higher for faceto-face students than online students without negatively impacting persistence. The institution should also consider additional funding for nontraditional face-to-face programs where tuition prices can be increased with no expected decrease in persistence and additional support for online programs to actively work to narrow the gap between persistence for nontraditional online student populations as compared to nontraditional face-to-face student populations. 


\section{CONTRIBUTIONS}

As discussed earlier, the literature review on tuition pricing for nontraditional student populations has limited studies that involve this population of students and even fewer studies that involve actual data at the student level rather than aggregate data from known national sources. There is limited research on how to connect this data at the student level back to theory such as Tuition Elasticity Theory and Elasticity Theory. With a strong motivation to address some of these shortfalls in actual student level data over aggregated data, this empirical case study uses tuition pricing to provide four important contributions to practice and theory including benefits to higher education institutions, customer relationship management softwares for students, administrators in higher education and other researchers in this field.

\section{VII.1 Contributions to Practice}

This empirical case study seeks to answer what is the effect a of tuition increase on nontraditional student persistence both online and in the classroom by demographics utilizing data at the student level. The coefficients resulting from this research can be used to more accurately estimate persistence by student demographic, setting realistic and attainable new student recruiting and enrollment goals to stifle attrition and grow a program, understanding how an increase in tuition price is likely to affect a given population of nontraditional students, and more accurately utilize institutional funds to grow existing programs with the understanding of the tuition effects on persistence.

The online findings concluding that as tuition rates are increased, the effect of a tuition increase on persistence for online nontraditional students is greater than that of face-to-face students is perhaps the largest and most significant finding of this study for its contributions to data points for further Tuition Elasticity Theory research as well as contributions to practice 
which can be immediately utilized by the studied University to begin further progress toward a sustainable pricing model for online nontraditional students utilizing the linear equation and resulting coefficients. This model can be updated quite easily as additional data is collected and analyzed and as additional model constructs are identified and studied. Utilizing programs like

Excel, spreadsheets can be developed to assist administrators in accurately using the coefficients to estimate persistence of their current nontraditional population as well as the effects of price increases by percentage.

This research may also provide valuable insights into predictive analytics for nontraditional students by segmented population allowing integration of such knowledge into customer relationship management (CRM) softwares commonly utilized by universities and colleges. These coefficients can can help the CRM administrator develop email and text campaigns targeted toward more at risk populations (those less likely to persist). Providing a deeper relationship and more frequent contact with the student utilizing a CRM system can result in increased retention and assumed increased persistence. Improving the use of the CRM with this data can also increase student loyalty and satisfaction which can have long term implications for higher education institutions through alumni engagement and giving (Seeman \& O'Hara, 2006).

\section{VII.2 Contributions to Theory}

Theoretically, this study furthers the conceptual understanding of the Tuition Elasticity Theory and Elasticity Theory providing an in-depth view of demographic effects in the educational sector for price responsiveness and elasticity by analyzing the coefficients resulting from a tuition increase and how those increases impact nontraditional student population persistence. The nontraditional student level data, rather than aggregated national or institutional 
level data, provides insight using empirical data rather than pricing survey data to render expanded elasticity understanding of different population sectors in tuition pricing methodologies through effects on persistence. This type of research helps investigate the evidence-based knowledge that either confirms the success of differentiating tuition pricing models as it relates to nontraditional student persistence or provides reasons for the exploration of alternative solutions through learned knowledge that helps create new models for tuition elasticity, if needed, through direct and indirect observation and experience.

This study allows researchers to consider the model of Tuition Elasticity Theory and building a case for changing the constructs of the model for studying nontraditional student populations. The current model contains constructs of tuition pricing and full time enrollment and the new model suggests either the definition of enrollment for nontraditional students must be modified or perhaps even a shift to or inclusion of persistence is worth additional studies. 


\section{CONCLUSION}

In conclusion, this study has both practical and theoretical implications; however, there are limitations to this study that are explained below. Future research opportunities that can further contribute to Elasticity Theory and Tuition Elasticity Theory as well as provide valuable insight for practice are elaborated on below.

\section{VIII.1 Limitations}

As in most studies, this one also has limitations, including only one university studied with a population of students in the southern region of the United States, thus possibly limiting the generalizability of research of this data set to all institutions serving nontraditional student populations. As this institution is a private, nonprofit institution with undergraduate data from four of the five campuses only, application may not be exactly generalizable to public or forprofit institutions; however, it can be expected that the findings are directionally accurate for nontraditional students.

As data from a secondary source is collected and managed by others, errors in this data cannot be controlled when collected by another individual (Smith, Budzeika et al. 1986). This secondary source also limits the amount of price changes that were followed with the level of data needed to be able to analyze the effects of the price changes on the different demographic populations.

Data was not collected for the sole purpose of tuition price increase effects on

persistence, thus students who elected to not persist for reasons other than price may have been included as information did not exist to exclude them from the data set. Data did not include in or out of state considerations, financial aid received, or the amounts of military or veterans assistance received. 
These limitations should not overshadow the statistical and economical significance of the findings and the resulting contributions to practice and theory as this study focuses on empirical longitudinal data at the student level versus aggregated data and survey data often used in other studies regarding tuition pricing. The limitations were managed to provide data that is reliable and valid to reduce bias and ensure rigor of the study.

\section{VIII.2 Future Research}

This study generates the need for future research on a larger level using student level data concerning differentiated tuition pricing for nontraditional population segments as well as studies including the budgetary constraints of the higher education institute. Additional studies, including graduate pricing, and doctoral pricing are also warranted.

As several of the findings were supported literature reviews including the findings involving military, females, and minority populations, additional research is recommended to explore the additional factors that are contributing to the effect of a tuition increase. As for the statistically significant findings of the nonmilitary nontraditional population, because this research did not include the impacts of tuition assistance and veterans assistance or separate the populations based on active duty, veteran, or reserve status, these results should not be generalized until further studies are completed detailing the impact by affiliation and even, perhaps, rank and branch.

Of notable statistical significance, those nontraditional students that did not disclose their ethnicity, for every 1 percent increase in tuition, increased their persistence by 0.4 percent, persisting less than nontraditional caucasian students but more than nontraditional minority students. While typically this may not be an interesting finding, it was the quantity of students that did not disclose that made this statistically significant finding interesting with 46.5 percent 
of the nontraditional student population opting out of disclosure. The question needs to be explored answering who are these individuals that do not wish to disclose. Why is there a difference in the effect on tuition increase on this group with regards to nontraditional student persistence?

It also may be prudent to study the effect of age on a continuous scale rather than a traditional or nontraditional dichotomous model to determine if certain trends exists within age brackets. It is possible that traditional age students may be behaving more like nontraditional aged students as they become employed to manage the shift in the amount of taxpayer funding [both Federal and State] to student funding of their tuition, paying more of the tuition out of their pocket (Fethke, 2014).

\section{VIII.3 Summary}

The research of Elasticity Theory and Tuition Elasticity Theory provides a good foundational knowledge to responsive pricing in the higher education industry; however, this research continues to build the underlying knowledge needed to advance the studies in the nontraditional student population in higher education. This study provides further data allowing generalizations about nontraditional student population response to tuition effects on their probability of persisting.

Students, if viewed through the lens of a customer, are a diverse population with different responsiveness to pricing models. This research shows overall that differentiated pricing results in a change in the probability of persistence for each population of student, both traditional and nontraditional. The coefficients showing the

effects of tuition price on the probability of persisting can be used to develop differentiated pricing models to show different responsiveness to pricing changes in relation to 
the likelihood to persist of nontraditional student populations. This research provides the first step to developing differentiated pricing models specifically for nontraditional student populations utilizing tuition elasticity .

The utilization of this research can reap immediate benefits for those seeking to have a better understanding of the tuition price on the likelihood of nontraditional student persistence allowing the advisors, administrators, higher education institutions, and customer relationship management software as service companies to estimate price increase effects, identify at-risk of not persisting nontraditional populations, target communication plans, and improve projections for persistence and enrollment. 


\section{REFERENCES}

Bryan, G. A., \& Whipple, T. W. (1995). "Tuition elasticity of the demand for higher education among current students: A pricing model." The Journal of Higher Education, 66(5), 560. Retrieved from http://search.proquest.com/docview/205336131?accountid=9858

Byrd, J., Roufagalas, J., \& Mixon, P. (2015). "Tuition Sensitivity in online education." Journal of Economics and Economic Education Research, 16(3), 25-41. Retrieved from https://search-proquest-com.proxy.campbell.edu/docview/1768624588?accountid=146941

Cameron, S., \& Heckman, J. (2001). "The dynamics of educational attainment for black, hispanic, and white males.” Journal of Political Economy, 109(3), 455-499. doi: $10.1086 / 321014$

Campbell. R., \& Siegal, B.N. (1967). "The demand for higher education in the United States, 1919-1964. The American Economic Review, 57(3), 482-494.

Chao, F. (2014). "Equilibrium tuition, applications, admissions, and enrollment in the college market." Journal of Political Economy, 122(2), 225-281.

Curs, B. R., \& Singell, J. D. (2010). “Aim high or go low? Pricing strategies and enrollment effects when the net price elasticity varies with need and ability. "Journal Of Higher Education, 81(4), 515-543.

Fethke, G. C., \& Policano, A. J. (2013). "Public no more universities: Subsidy to self-reliance." The Journal of Management Development, 32(5), 525-536. doi:http://dx.doi.org/10.1108/02621711311328291

Fethke, G. (2014). "Decentralized university budgeting, united with a more flexible tuition structure.” Journal of Education Finance 39(4), 323-343. University of Illinois Press. Retrieved September 18, 2015, from Project MUSE database.

Funk, H. J. (1972). "Price elasticity of demand for education at a private university." Journal of Educational Research, 66 (1972), 130-34.

Heller, Donald E. (1997). "Student price response in higher education: An update to Leslie and Brinkman." The Journal of Higher Education 68.6(1997), 624-659.

Hemelt, S. W., \& Marcotte, D. E. (2011). "The impact of tuition increases on enrollment at public colleges and universities." Educational Evaluation and Policy Analysis, 33(4), 435457. Retrieved from http://www.jstor.org.proxy.campbell.edu/stable/41413066

Houck, J. P. (1967). "Price elasticity and linear supply curves." American Economic Review, 57(4), 905.

Jenkins, R. (2012). "The new traditional on campuses." The Chronicle of Higher Education, Retrieved from http://search.proquest.com/docview/1114004714?accountid=9858 
Kane, T.J. (1995). "Rising public college tuition and college entry: How well do public subsidies promote access to college?" Cambridge, MA: National Bureau of Economic Research Working Paper Series No. 5164.

Kim, Jiyun. (2010)."The effect of prices on postsecondary access: An update to Heller." Higher Education in Review 7.

Leslie, L. L., \& Brinkman, P. T. (1987). "Student price response in higher education: The student demand studies." The Journal of Higher Education, 58(2), 181-204.

National Center for Educational Statistics (NCES). (2017, April). "Undergraduate Retention and Graduation Rates.” Retrieved from https://nces.ed.gov/programs/coe/indicator_ctr.asp

Parry, M. (2012). "No financial aid, no problem. For-profit university sets \$199-a-month tuition for online courses." The Chronicle of Higher Education, Retrieved from http://search.proquest.com/docview/993137681?accountid=9858

Rothschild, M., \& White, L. (1995). "The analytics of the pricing of higher education and other services in which the customers are inputs." Journal of Political Economy 103(3), 573-586.

Seeman, E. D., \& O'Hara, M. (2006). "Customer relationship management in higher education: Using information systems to improve the student-school relationship." Campus - Wide Information Systems, 23(1), 24-34. Retrieved from https://search-proquestcom.proxy.campbell.edu/docview/218053480?accountid=146941

Semega, J. L., Fontenot, K. R., \& Kollar, M. A. (2017, September). "Income and poverty in the United States." U.S. Census Bureau. 2016. Retrieved from https://www.census.gov/data/tables/2017/demo/income-poverty/p60-259.html

Shin, J. C., \& Milton, S. (2008). "Student response to tuition increase by academic majors: Empirical grounds for a cost-related tuition policy." Higher Education, 55(6), 719-734.

Smith, D. E., \& Mitry, D. J. (2008). "Investigation of higher education: The real costs and quality of online programs." Journal of Education for Business, 83(3), 147-152. Retrieved from http://search.proquest.com/docview/202821007?accountid=9858

Smith, P. C., Budzeika, K. A., Edwards, N. A., Johnson, S. M., \& Bearse, L. N. (1986). "Guidelines for clean data: Detection of common mistakes." Journal of Applied Psychology, 71(3), 457-460. doi:10.1037/0021-9010.71.3.457.

St. John, E. P., (1994). “Assessing tuition and student aid strategies: using price-response measures to simulate pricing alternatives." Research in Higher Education 35(3), 301-334.

St. John, E. P., (1990). "Price response in persistence decisions: an analysis of the high school and beyond senior cohort." Research in Higher Education 31(4), 387-403. 
State Higher Education Executive Offices (SHEEO) (2014). "SHEF - State higher education finance, FY14", available at: http://www.sheeo.org/sites/default/files/projectfiles/SHEF\%20FY\%202014-20150410.pdf (accessed November 21, 2015).

U.S. Census Bureau. (2016a). "Male/female earnings.” Retrieved from https://www.census.gov/library/visualizations/2017/comm/sm-female-earned.html

U.S. Census Bureau. (2016b). "1968 to 2017 Annual social and economic supplements: real median household income by race and hispanic origin: 1967 to 2016." Retrieved from https://www.census.gov/content/dam/Census/library/visualizations/2017/demo/p60259/figure1.pdf

U.S. Department of Homeland Security. (2018, January). "2018 Base Pay.” Retrieved from https://www.dcms.uscg.mil/Portals/10/CG-1/PPC/docs/2018BasePay.pdf 


\section{VITA}

Working as a C-Suite professional, Katherine Spradley dedicates her energy to helping institutions manage risk, pursue strategic opportunities, and achieve operational excellence.

Spradley's extensive finance and technology background is derived from vast experience in big banking that later focused on the lending sector for individuals, corporations, and trusts at Wachovia Bank, NA, ultimately resulting in developing a new underwriting platform for the bank and new training guides for underwriting to address compliance needs.

Spradley currently serves the Chief Information Officer at a non-profit educational institution in central North Carolina responsible for the implementation and management of the student information system, accreditation, and gathering, coordinating, maintaining, and gate keeping institutional information and technology.

Spradley is also the founder of K. Cradley and Company, a consulting firm specializing in strategic planning, project management, information management, analytic decision making, professional development, program development \& expansion, technology expansion and management, and comprehensive training and documentation.

Prior to serving as Chief Information Officer, Spradley served as the founding Director of Campbell University Online strategically planning and launching the first online programs for the University as well as serving as a System Administrator for the Learning Management System. Responsibilities were delicately balanced between two distinct missions including the training and education of faculty and staff preparing them to teach online and hybrid courses and preparing to graduate scholars with exemplary academic and professional skills through marketing, recruiting, and assessing all online undergraduate programs, developing, auditing, and managing all online course offerings; and recruiting, coordinating, training, and supervising online faculty and staff. Spradley has remained Campbell University serving as a Professor of Business for the Lundy-Fetterman School of Business.

Spradley has a doctorate in Business Administration from Georgia State University, an MBA in Management from Strayer University, and a Bachelor of Business Administration in Trust and Wealth (Investment) Management with a minor in Financial Planning from Campbell University in Buies Creek, North Carolina. She is a research associate with the Georgia State University Center for Engaged Research and currently serves on a non-profit educational board of directors serving on the Finance Committee and chairing the Accreditation Committee.

Spradley resides in Erwin, North Carolina with her husband Seth and three children, Henry, Charles, and Nev. 